\title{
Regional varieties of Italian in the linguistic repertoire
}

MASSIMO CERRUTI

\begin{abstract}
This paper focuses on regional Italian as a special observatory for both synchronic and diachronic variation in Italian. After a brief overview of some key concepts (Section 1) and the state of the art (Section 2), I consider regional Italian in a language-contact perspective (Section 3). In addition, I analyze it from the viewpoint of the reciprocal relationship between dimensions of linguistic variation (Section 4). The topics addressed here range from the process of language shift from Italo-Romance dialects toward Italian to the decreasing regional markedness of contemporary Italian. They therefore include issues related to native-like competence, ongoing restandardization, and developmental tendencies in Italian.
\end{abstract}

Keywords: linguistic variation; language contact; regional Italian; standardization.

\section{Regional varieties of Italian and Italo-Romance dialects}

The sociolinguistic situation of Italy is characterized by the presence of regional varieties of Italian, which is spoken alongside more than fifteen ItaloRomance dialects ${ }^{1}$ and about fifteen historical linguistic minorities (besides a certain number of new linguistic minorities). Like the geographical dialects of British and American English, the regional varieties of Italian are varieties of the national language that are spoken in different geographical areas. They differ both from each other and from standard Italian (henceforth SI) at all levels of the language system, especially with regard to phonetics, phonology and prosody, and represent the Italian actually spoken in contemporary Italy. Common Italian speakers regularly speak a regional variety of Italian, which is termed regional Italian (henceforth RI).

According to the Coserian distinction among primary, secondary, and tertiary dialects (Coseriu 1980), regional varieties of Italian should henceforth be 
understood as tertiary dialects; they are varieties resulting from the geographical differentiation of the standard language after its social diffusion. ItaloRomance dialects should instead be understood as primary dialects, since they are coeval geographical varieties of the dialect from which the standard language descends (Berruto 2005: 81-83). Therefore, we have to do with intralinguistic variation in the former case, and with interlinguistic variation in the latter case.

\section{Research on regional Italian: twenty years on (and beyond)}

There is generally agreement that scientific research on RI begun after the first half of the twentieth century, with an investigation carried out by Rüegg (1956) on the geographical variation of Italian lexicon. This pioneering work was followed by fundamental theoretical discussions and descriptive surveys. The former had focused on the boundaries and the reciprocal relationships among dialects, RI, and social and situational varieties of Italian within the linguistic repertoire (cf. the bibliography in Berruto 1989: 9-12). The latter developed particularly in the second half of the 1970s and were mainly devoted to the detection of linguistic features that could describe and distinguish each regional variety of Italian. Cortelazzo and Mioni (1990) offer a first assessment of both perspectives, following approximately thirty years of research (cf. Cerruti [2009: 17-25] for an updated bibliographic review).

Although less steadily than before, the last two decades have produced a wealth of research in RI, which also contributed to the ongoing theoretical and methodological debate in the field (cf. Telmon 1990, 1993; Benincà 1994; D'Achille 2002; Fusco and Marcato 2001; among others). More recently, studies on RI have mostly focused on specific aspects (even specific linguistic features) of single regional varieties, taking various perspectives based on different research traditions. Along with the well-established approach within the framework of the history of the Italian language (e.g. Bruni 1992) and the more recent approaches that deal with Computational Linguistics (Cucurullo et al. 2006) and Corpus Linguistics (Pandolfi 2006, 2009), it is possible to pinpoint at least five prevalent approaches (partially overlapping), which relate in various ways to different subfields of Linguistics:

a) General Linguistics, with a particular focus on syntactic theory (cf. e.g. Benincà and Poletto 2006; Garzonio 2008; Penello and Pescarini 2008; Berruto 2009);

b) Contact Linguistics, mainly devoted to the study of substratum interference phenomena (cf. e.g. Berruto 2005; Sornicola 2006; Benincà and Damonte 2009; Cardinaletti and Munaro 2009; Cerruti forthcoming a); 
c) Sociolinguistics and variation analysis, also broadening out into matters of Sociology of Language (cf. e.g. Conti and Courtens 1992; Alfonzetti 1997; Binazzi 1997; Amenta 1999, 2008; Berruto 2003; Miglietta and Sobrero 2003; D'Achille and Viviani 2003; Fusco 2004; Regis 2006; Sobrero 2006; Boario 2008; Cerruti 2007, 2009);

d) Geolinguistics (cf. e.g. Sobrero et al. 1991; Ruffino 1995; Tempesta 2002);

e) Folk Linguistics and Perceptual Dialectology (cf. e.g. Stehl 1995; Antonini and Moretti 2000; Cini and Regis 2002; Binazzi 2007).

The approach I follow here derives from perspectives taken from both Contact Linguistics and Sociolinguistics, and aims to offer also some findings that may be of interest to those involved in the Sociology of Language.

\section{Regional Italian in the framework of language contact phenomena}

Until the early twentieth century, Italian was almost exclusively used in writing and formal styles. It was in a diglossic relationship with a dialect (the language for daily use), and it was mastered by a minority of the population (cf. Dal Negro and Vietti, this issue).

The use of Italian has progressively increased during the twentieth century due to factors of social change such as the gradual spread of education, the introduction of compulsory military service (that brought together for the first time speakers from different regions, hence speakers of different dialects), the transition from an agrarian society to an industrial society, and the advent of modern mass communication. Italian has thus gradually enjoyed diffusion both in domains formerly reserved to the use of dialect and among the previously monolingual dialect speakers.

At that time, dialect speakers were engaged in a process of group second language acquisition. Italian scholars have suggested to consider RI, and in particular its social varieties spoken by less educated speakers - the so-called italiano regionale popolare ('folk' RI), or simply italiano popolare ('folk' Italian) - along the lines of interlanguages in second language acquisition (Telmon 2001). The imperfect learning of Italian by dialect speakers has subsequently favored the occurrence of dialect features in varieties of Italian. The regional varieties of Italian have therefore derived from this process.

Substratum interferences are thus to be attributed to the effects of a process of language shift from dialects toward Italian (a process that is still under way). With respect to the typical language-shift scenario, the contact between dialects and Italian displays however some exceptions, which are mostly due to the particular lingua cum dialectis repertoire. One of the clearest examples is certainly that the sociolinguistic situation of Italy does not show the existence 
of a shifting minority group of speakers of the source language (i.e. an ItaloRomance dialect) separated from a majority group of native speakers of the recipient language. Moreover, if by recipient language we mean SI, there are surely no native speakers of such a variety (see below).

Hence, RI represents on the one hand the outcome of a process of unilateral convergence, or advergence (Advergenz [Mattheier 1996: 34]) from dialects toward Italian, and on the other hand, as in the typical case of formation of tertiary dialects (see Section 1), RI is also the outcome of a process of divergence of geographical varieties from the national language; it results from a so-called "dialectization of (varieties of) Italian" (Berruto 2005: 83). Far from determining linguistic unification, advergence has caused an increasing differentiation across the national linguistic repertoire.

The formation of "folk" regional varieties of Italian has then turned into a set of shared interference features transcending regional boundaries, which was the basis for the presumed standardization of modern italiano regionale popolare (Berretta 1988: 768; Stehl 1995: 56-57). Put more simply, after a first stage in which individual learners created their own interlanguages, some of the previously idiosyncratic dialect interferences have presumably become fossilized, resulting into a new established common grammar, which is characterized by sub-systems of co-occurrent fossilized interferences. This common grammar of italiano regionale popolare, comprising region-specific features in minor details, has thus become available as a target language for young people involved in the primary socialization process, at least until they entered the school system.

As a matter of fact, since the mid twentieth century most dialect speakers have started speaking to their children in their own socio-geographical variety of Italian. Educating children to speak only Italian was believed to ensure social enhancement. Those socio-geographical varieties of Italian have therefore become the mother tongue of those new generations. The younger generations represent by now a substantially compact age group of native speakers of RI, whose parents are in many cases native speakers of an Italo-Romance dialect. As discussed in Berruto (2003), this can be of further theoretical interest for issues related to native-like competence and, more generally, it can cast doubts on some traditional definitions of the concept of native speaker.

Ruling out possible exceptions, there are no native speakers of SI (especially with regard to phonetics, phonology and prosody; see Section 4.1). Incidentally, not even a native speaker of the Tuscan or Florentine variety of Italian could be considered a native speaker of SI, since in Tuscan or Florentine Italian there are certain features that do not belong to the so-called fiorentino emendato (literally 'amended Florentine' [Galli de' Paratesi 1984: 57]), which forms the basis for SI. In other words, typical Tuscan features, such as the presence of third person subject clitics (e.g. la parla 'SCL-she talks') or the well-known 
gorgia (see Section 4.1), in addition to various regional lexical peculiarities (cf. Binazzi 1997), are excluded from the norm of SI.

To return to a language-contact perspective, the process of formation of RI briefly sketched above recalls some typical aspects of group second language acquisition: 1) fossilization mainly affects sub-systems of the interlanguage; 2) a common grammar arises after initial idiosyncratic transfers; and 3) different developmental stages in the acquisition process entail different versions of the target language. This process is also characterized by substratum interferences which result, as in typical cases, "from imperfect group learning during a process of language shift" (Thomason and Kaufman 1988: 38). The fact that RI has then become the mother tongue of the following generations, and the (spoken) language of the entire national speech community, recalls typical aspects of creole formation (obviously retaining clearly visible sociolinguistic differences; cf. D'Achille 2002). More specifically, similarities can be seen with those creoles emerging from learning varieties of a superstrate language (cf. Cerruti forthcoming a).

\subsection{Standard regional Italian and neo-standard Italian}

The diffusion of certain regional features both in "folk" RI and in RI spoken by educated speakers (also termed "educated RI") has consequently given rise to a regional norm that is socially accepted and shared; this norm may be referred to as "standard RI" (Berruto 1987: 19). Concerning pronunciation in particular, a number of standard regional varieties of Italian have thus grown, i.e. varieties of Italian that, in spite of their geographical markedness, are commonly spoken by more and less educated speakers and constitute an accepted norm, which coexists with the standard national one (cf. also Fusco 2004: 282-286).

Contemporary Italian is undergoing a restandardization process, caused by the mutual interrelation between spoken and written language (and related to the ongoing spread of Italian as language for daily use in the context of the social changes mentioned in Section 3 ) and the consequent acceptance of previously non standard features into the standard ones. This new emerging standard variety, which is termed "neo-standard Italian" (Berruto 1987: 23), allows a certain amount of regional differentiation. In other words, region-specific (standard RI) features are equally accepted and commonly used also by the most educated speakers and are embedded in a number of nationally shared linguistic traits, mainly concerning morphosyntax.

It is a process that affects pronunciation likewise. It is leading in particular to a pronunciation that disregards phonetic and phonemic distinctions not conveyed in writing. We may single out different (neo-)standard variants. Canepari (2005: 23-26), for example, sees the coexistence of four types of standard 
pronunciations: "traditional" (Florentine based), "modern", "acceptable" and "tolerated", each one of them used by broadcasters, dubbers and actors, and no one strongly regionally marked. At the same time, different standard regional pronunciations have been established.

This may rest on a fuzzy categorization of the concept of standard language itself. As remarked by Ammon (2004), the standard variety of a language can indeed be considered as having a core of undoubtedly standard forms and somehow fuzzy boundaries, as well as a number of borderline cases, which can account for a complex gradation between standard and non standard. Such a prototypical concept of standard rests upon the existence of a "colloquial standard" as well; in particular, it calls upon the concept of Umgangssprache. It is not by chance that neo-standard Italian itself displays Umgangssprache characteristics (cf. Berruto 1987: 141). ${ }^{2}$

The case of Switzerland Italian should be treated separately. Italian is one of the four official national languages in Switzerland; it is spoken in the Cantons of Ticino and in part of Grisons, and must not be considered merely as a RI. In actual facts it is a national standard language partly different from the Italian one (mainly at the lexical level). It displays some peculiar norms and tendencies of development, which are related both to the contact with the other national languages of Switzerland and to the political and administrative organization of the state body. In this perspective it was hence proposed to consider Italian as a pluricentric language (Pandolfi 2009: 12-13).

\subsection{One common grammar, different grammars?}

In the framework of language contact phenomena, research on standard RI seeks to shed light on which factors, principles or mechanisms affect the selection (or conventionalization) of linguistic features as a part of a common grammar. The results of a recent research carried out in Turin show that the set of morphosyntactic features of Piedmontese standard RI can be characterized as follows (Cerruti 2009: 235-270):

a) high consistency with universal (that is, system-independent) naturalness principles; besides cases of naturalness conflicts, it shows only a few cases of marked features, mainly on the border between lexicon and morphosyntax;

b) general structural adequacy to the system of SI; that is, general consistency with system-dependent naturalness principles;

c) linguistic features that fit in with restandardization tendencies in neostandard Italian, even though showing peculiar distributional or structural features; for example, the regional progressive periphrasis essere quilli 
che+Verb (literally, 'to be here/there that'+Verb) undergoes the same development of the corresponding neo-standard stare+Gerund (literally, 'stay'+Gerund) along the common path of "PROG imperfective drift" (Bertinetto 2000), but, unlike that, it embraces a more advanced developmental stage; differently from stare+Gerund in neo-standard Italian (see Section 3.3), essere quilli che+Verb turns out to be compatible with focalized as well as non-habitual and habitual durative contexts (cf. also Cerruti 2007);

d) linguistic features that do not match any grammaticalized construction in standard or neo-standard Italian (cf. an example in Section 4.1).

Facilitating factors play a role in the retention of substratum features and the establishing of some of them as a part of a common standard regional grammar of Italian. Such factors are similar to those at work in both group second language acquisition and creole or post-creole continuum formation. In addition, they can be found in various language contact situations (among which, the contact between Italo-Romance dialects; cf. e.g. Parry 2006). They include: a) naturalness and transparency; b) system adequacy; c) congruity with innovational tendencies of the recipient language; d) filling of structural gaps in the inventory of the recipient language (cf. Cerruti forthcoming a). These internal factors obviously interplay with external or extralinguistic forces of a social, pragmatic, interactional, psychological, and demographic kind (cf. e.g. Miglietta and Sobrero [2003] on the contact between Italian and dialects).

Factors b) and c) in Piedmontese standard RI are of particular interest for the general issue concerning structural differences between regional varieties of Italian and SI. It must be remembered that the presence of constructions that are not consistent with standard or neo-standard Italian is indeed widely attested in Piedmontese "folk" RI and in other varieties of italiano regionale popolare.

An emblematic case is the doubly filled complementizer (e.g. quando che è arrivato 'when that he arrived' vs. SI quando è arrivato 'when he arrived'), which occurs in many varieties of italiano regionale popolare (Piedmontese, Lombard, Ticinese, Emilian, Veneto, Friulian, Abruzzese, Calabrian, Apulian, Sicilian, etc.; cf. Berruto 2009). Due to its over-regional presence, it can be considered as one of those fossilized interferences that form the basis for the aforementioned common grammar of italiano regionale popolare (see Section 3). It violates the so-called Doubly Filled Comp Filter, a restriction that excludes the co-occurrence of $w h$-phrase and complementizer in a Comp position, and that is fully operative in SI. This raises the question of whether deeplevel differences exist between SI and social varieties of RI.

Up to now, italiano regionale popolare is characterized by relatively lasting co-occurrences of fossilized dialect interferences - that generally fall outside 
Table 1. Singular personal pronouns in "folk" Northern RI (italics) and in SI (roman)

\begin{tabular}{|c|c|c|c|}
\hline & SBJ & OBJ (strong pronouns) & OBJ (clitic pronouns) \\
\hline $1 \mathrm{SG}$ & $\mathrm{MF}$ io / me & MF me / me & MF mi / mi \\
\hline $2 \mathrm{SG}$ & MF tu / te & MF te / te & MF ti / $t i$ \\
\hline $3 \mathrm{SG}$ & $\begin{array}{l}\text { M egli (lui) / lui } \\
\text { F ella (lei) / lei }\end{array}$ & $\begin{array}{l}\text { м lui / lui } \\
\text { F lei / lei }\end{array}$ & $\begin{array}{l}\text { м lo / lo 'him', f la / la 'her' } \\
\text { м gli 'to him', F le 'to her' / MF } c i \\
\text { 'to him, to her' }\end{array}$ \\
\hline REFL & - & MF sé / M lui F lei & MF si / MF si \\
\hline V-form ${ }^{3}$ & MF lei / м lui F lei & MF lei / м lui F lei & $\begin{array}{l}\text { MF la 'you' / м lo F la 'you' } \\
\text { MF le 'to you' / m ci F le 'to you' }\end{array}$ \\
\hline
\end{tabular}

the core grammar - resulting in certain cases in sub-systems of interrelated features, which differ from the corresponding sub-systems of SI (Berretta 1988: 763-768). Consider for instance Table 1, which reports the set of singular personal pronouns (with an animate referent) in "folk" Northern RI compared with the one in SI.

From a theoretical perspective, these differences can be attributed either to the existence of separate or competing grammars speakers choose from (which entails more than one system of grammatical knowledge in the competence of native speakers) or to the existence of a unique grammatical system which embodies variability through different kinds of mechanisms (e.g. optional or variable rules). It may be also possible to localize variation outside the grammatical system itself, as a separate mechanism that interacts with the syntax (recent minimalist approaches localize variation in the choice of lexical items). These aspects, which are also of fundamental interest for the issue of the native-like competence of Italian (see Section 3), have been addressed in recent research (cf. among others Berruto 2009; Benincà and Damonte 2009; Cerruti forthcoming a). According to the so-called micro-comparative approach applied to the Italo-Romance situation, variation between grammars is considered in particular as variation regarding specific constructions between otherwise identical grammars (Benincà and Damonte 2009: 186).

\subsection{Italo-Romance dialects and regional varieties of Italian: common paths of development}

Italo-Romance dialects and regional varieties of Italian are generally going through similar stages of common developmental paths, which are furthermore often widely shared by Romance languages. The well-known conditions of intensive and long-term contact between dialects and Italian certainly play a role in this process, together with factors related to the common inheritance and genetic drift. ${ }^{4}$ Interestingly, SI is frequently at a different developmental 
stage when compared to its regional varieties; broadly speaking, it seems to be more conservative than its non-standard varieties. It may be worth considering the following few examples regarding verbal morphology.

As for the tendency to generalize a HAVE-type auxiliary as perfect auxiliary, which is lasting and widespread in Romance, SI is the Romance language that makes the greatest use of a BE-type auxiliary (essere). Some Italo-Romance dialects and non-standard varieties of Italian tend instead to generalize the HAVE-type auxiliary, according to the general Romance tendency. In particular, Southern and North-Eastern dialects show an advanced stage along this path (Posner 1996: 15-24), and the related regional varieties of Italian seem to proceed in the same direction (as recently pointed out in Cordin [2009] regarding Trentino RI). The generalization of the HAVE-type auxiliary also emerges in neo-standard Italian (cf. Berruto 1987: 120).

In most Romance languages, as well as in other European and non-European languages, progressive periphrases are undergoing the evolution into merely imperfective forms (that is, to a general-purpose imperfective tense). The Italian progressive periphrasis stare+Gerund is expanding in use in neo-standard Italian as well. It has focalized progressivity as its main reading, and it is available to the non-habitual durative meaning at once. Conversely, it is still restricted to focalized contexts in SI. Some regional varieties of Italian, such as the Sicilian and Sardinian ones, are at a more advanced stage along this imperfective drift, reflecting the developmental stage of the substrata; stare + Gerund occurs with focalized as well as non-habitual and habitual durative meaning in Sicilian RI (Amenta 1999; cf. essere quilli che+Verb in Piedmontese RI, Section 3.2) and even with stative verbs in Sardinian RI (Loi Corvetto 1982: 149153).

Contemporary Italian shows a marked tendency to develop phrasal verbs (e.g. dare indietro 'to give back'; tirare su 'to bring up', literally 'to pull up'; scappare via 'to get away', literally 'to escape away', etc.). Not only are these constructions typologically inconsistent with the verb-framed type that generally characterizes the Romance languages, but their spreading across Italian seems to have no equal in other Romance languages. They are especially widespread in Northern varieties of Italian, as well as in Northern dialects (cf. Cini 2008).

The case of phrasal verbs is also a good example of the way closely related languages share developmental paths, partly because of contact-induced evolution and partly because of similar but independent inner dynamics. The contact of Italian with Northern dialects, as well as with bordering Germanic languages (that fall into the satellite-framed type), has inevitably contributed to the great development of phrasal verbs in Northern regional varieties of Italian. Nevertheless, the creation of phrasal verbs derives from structural and typological changes which have taken place both in dialects and in Italian. Among 
others, it is worth mentioning the shift from Latin SOV to Romance SVO order, the disappearance of the Latin inflectional case system in modern Romance and its replacement by prepositions, the progressive loss of transparency and productivity of prefixes (cf. Iacobini and Masini 2009). Evidence of this can be found in the spread of phrasal verbs even in regional varieties whose substratum dialect does not show an equally wide diffusion of such constructions (as in Sicilian RI; Amenta 2008).

Moreover, conflicting contact-induced tendencies and language-internally motivated tendencies can coexist within the same regional variety of Italian. By way of example, Compound Past (e.g. ho scritto, sono arrivato, 'I have written', 'I have arrived') is taking over the functions of Simple Past (e.g. scrissi, arrivai, 'I wrote', 'I arrived') in contemporary Italian and it is inclined to generalize into perfective, according to a pan-Romance and European tendency (Bybee et al. 1994: 81-87). Northern varieties of Italian uniformly show an advanced stage along this path. On the contrary, some Southern varieties are characterized by conflicting tendencies. In Sicilian RI, for instance, the language-internally motivated Compound Past diffusion is restrained by the contact-induced maintenance of Simple Past, which is well-established in the Sicilian dialect (Alfonzetti 1997: 15-17).

These few examples seem to suggest that a process of convergence among the different regional varieties of Italian is in fact under way. Such process tends to reduce the (socio-)geographical markedness of previously marked constructions.

Nevertheless, with respect to a given phenomenon, even the same regional variety can embrace different stages of development according to sociodemographic and situational factors. The generalization of Compound Past in Sicilian RI shows a later stage in younger speakers and in informal style (Alfonzetti 1997: 43-44); phrasal verbs are more widespread in colloquial varieties of Italian, without relevant regional differences (Iacobini and Masini 2009); stare+Gerund in Sicilian RI behaves more like a purely imperfective form in less educated speakers and in informal styles (Amenta 1999: 98); the generalization of the HAVE-type auxiliary in Trentino is at a more advanced stage in "folk" RI (Cordin 2009: 88-93), etc.

In conclusion, it is worth remembering that in these cases - as in many others - restandardization tendencies do not lead to the creation of constructions formerly unattested in Italian. Most neo-standard features, that at first glance appear to be recent innovations, are already present in ancient Italian (cf. D'Achille 1990). Despite their exclusion from the standard literary variety, they have survived over the centuries in non-standard varieties, and have subsequently standardized in contemporary Italian only. Hence, what seems truly new is the acceptance of these constructions into the Italian norm (cf. Section $3.1)$. 


\section{Dimensions of linguistic variation}

As is well known, every language is composed by a number of hierarchically related varieties, depending on the reciprocal relationship between the dimensions of linguistic variation. According to the continental European tradition, we refer to the three main dimensions of synchronic variation as diadimensions: diatopia (variation across space), diastratia (variation across socio-economic classes and social groups) and diaphasia (variation across situations). As for Italian, diatopia is considered the primary dimension of variation: every regional variety of Italian has its social varieties ("folk" RI, educated RI, standard RI) and - as well as each of its social varieties (except for popular RI, in some ways; see below) - encompasses situational variability. Hence, Italian differs from English, whose primary dimension is often considered to be diastratia (according to Bell's Audience Design model; diaphasia instead is thought to be the basic dimension according to Finegan and Biber's Register Axiom; cf. Biber and Conrad [2009: 264-267]); also, consider French, whose primary dimension is considered to be diaphasia (Gadet 2007).

In general, regional varieties of Italian are not employed as situational varieties. An exceptional case is currently represented by Roman Italian: Mainly among the younger generation, it seems to be spreading nation-wide as an informal style of Italian (and particularly in computer-mediated communication; cf. Scholz 2003: 135).

No social varieties of RI are generally employed as situational varieties either. An exception is the use of "folk" RI as "elderspeak", which is the use of italiano regionale popolare - even by highly educated young speakers - in cross-generational talk with elders (cf. Sogni 2004). Another exception concerns uneducated speakers: italiano regionale popolare represents a situational variety of their linguistic repertoire. It is the only variety of Italian these speakers master - it does not encompass diaphasic variability ${ }^{5}$ - and they use it only in formal situations, notably in writing. On the whole, "folk" RI therefore represents the high variety of the repertoire of uneducated speakers, while the dialect represents the low one.

\subsection{Diatopia and diaphasia}

Certain features of RI also work as markers of informal style. The production of a given regional feature is subject to greater control in formal styles. For instance, the sociolinguistic variable $(K)$ in Roman Italian is realized as palatal approximant in colloquial speech (e.g. Roman Italian [bi'j:et:o] vs. SI [bi' $\kappa: e t: o]$, 'ticket'); instead, the production of the standard variant $[K]$ of the regional variant [j] is a clear sign of shift towards a more formal style (D'Achille 2003: 33). 
Nevertheless, sociolinguistic variables in Italian do not generally show the typical Labovian prestige pattern, particularly in phonetics. Pronunciation is less subject to the pressure of the standard norm than other levels of the language system; even at school, phonetic regional or non-standard variants that do not clearly conflict with phonetic and phonemic distinctions conveyed in writing are widely tolerated (cf. Section 3.1).

Pronunciations without any regional features are extremely rare even among educated speakers and in very formal situations (cf. also Sobrero 2006: 331333). For instance, a research carried out on Bolognese Italian (Rizzi 1989: 113-119) points out that the sociolinguistic variables $(K),(\mathrm{n})$, and $\left(\int\right)$ are realized with the typical Northern variants even by educated speakers and in careful speech: i.e. as [lj], [nj], and [sj], respectively (e.g. Northern RI ['a:ljo] 'garlic', ['so:njo] 'dream', ['sjarpa] 'scarf' vs. SI ['a $\kappa: 0]$ [ ['son:o], ['Jarpa]).

The case of Tuscan regional Italian represents an exception in this scenario (partly due to its sociolinguistic peculiarities). Sociolinguistic variables often show a typical Labovian pattern. With regard to the Tuscan gorgia, for instance, the spirantization of intervocalic voiceless plosives is sensitive both to style and social stratification. As for the variable $(\mathrm{k})$, the production of the regional variants $[\mathrm{x}],[\mathrm{h}]$, and $\varnothing$ in Florentine is much more common among lower classes and less formal styles than among upper classes and more formal styles (Giannelli and Savoia 1978).

Moreover, according to one of the main sociolinguistic findings upon style (cf. Labov 2001: 86), style-shifting is related to the social awareness of a sociolinguistic variable. In other words, the unawareness of the sociolinguistic markedness of a given linguistic feature can cause this feature to be insensitive to style stratification. This is even more so for regional markedness. Italian speakers are often unaware that a given linguistic feature is regionally marked and, all the more so, that this is due to substratum interference. All things being equal, the older speakers are obviously more aware of substratum interferences, while the younger speakers are less so. As a result, the former tend to avoid using these features, especially in formal style, while the latter may not reject their usage even in formal style (cf. e.g. Poletto 2009).

In addition, the lack of social markedness of a given regional feature can favor its occurrence both in informal and in formal styles. Features of standard RI may thus be scarcely sensitive to style variation, since they are commonly shared - and then socially unmarked - within a certain geographical area. As for morphosyntax, for instance, the focus adverbial solo più (literally 'only more'; e.g. c'è solo più un biglietto 'there is just one ticket left'), a feature of Piedmontese standard RI that does not match any grammaticalized construction in SI, is found to occur equally in colloquial speech and in essay writing, fiction, journalism, and bureaucratic prose (Regis 2006: 276-279). In contrast, it is possible to find standard RI variants that are sensitive to style variation, 
as in the case of certain phrasal verbs (e.g. Piedmontese standard RI mettere addosso, mettere su, informal variants of (indossare) 'to wear'; Cerruti 2009: 131-133).

In a given regional variety of Italian there are thus variables that have stylistic variation but substantially no social variation (see (indossare) in Piedmontese standard RI ${ }^{6}$ and variables that have social variation but substantially no stylistic variation (see the complementizer variable, Section 3.2). This state of affairs is given high relevance in the theoretical framework of the relationship among language varieties, in particular with reference to the aforementioned Bell's and Finegan and Biber's stances (see Section 4; cf. Cerruti forthcoming b). As generally known, Bell claims that the primacy of social variation (in English) makes the range of social variation to be wider than the range of style variation, while Finegan and Biber claim that the primacy of style variation causes the opposite. In principle, it follows that in the former case no variable will have style variation only, and in the latter none will have social variation only. In order to fully understand why Italian seems to behave differently from English, one should bear in mind that the former has neither diastratia nor diaphasia as its primary dimension of variation.

\subsection{From contact-induced changes to intra-linguistic variation}

As I mentioned earlier (see Section 3; Dal Negro and Vietti, this issue), Italian has been used almost exclusively in writing and in formal styles for centuries. During the twentieth century it has enjoyed mass-diffusion and gained expressive means for informal styles. Substratum interferences have contributed to widening the range of style variation, giving rise to regional variants that are stylistically stratified. Italo-Romance dialects have thus come to create sets of variants previously not existing in Italian; see for instance in Piedmontese RI the following set that ranges from the most formal variant to the less formal one: investirsi (SI), scontrarsi (SI), bocciare (standard RI), andarsi addosso (SI), darsi dentro (popular RI) 'to collide' (said of motor vehicles).

Intra-linguistic variation often originates from contact-induced changes. Some peculiar outcomes can be summarized as follows. In Piedmontese RI, the sociolinguistic variables (benché) 'although', (finché) 'until', and (perché) 'so that' are realized with two regional variants each: ben che, fin che, per che, i.e. with analytic structure - as in the substratum dialect, source of the interference - by old and less educated speakers (with Piedmontese dialect as L1); bénche, finche, pérche, i.e. with synthetic structure - as in SI benché, finché, perché - and stress on the penultimate syllable are used by young and more educated speakers (native speakers of Piedmontese RI). Both variants 
have the same phonological form: ['beyke], ['finke], ['perke]. These variables have, therefore, only one regional variant at the surface level, ['beyke], ['finke], ['perke], which is the standard RI variant, but two different structural variants at a deep level: ben che, fin che, per che and bénche, finche, pérche; the former is typically the "folk" RI variant, whereas the latter is the educated RI variant. It is thus arguable that, after the transfer from dialect to Italian, the originally morphosyntactic feature has fossilized and then passed from one generation to another by turning into a prosodic feature of RI. We propose the term "covert variants" to refer to sociolinguistic variants of this kind, which are hidden at the surface level (Cerruti forthcoming a).

A similar example, taken from Veneto RI, is given by constructions such as li si leggono (literally 'them one read' vs. SI li si legge 'one reads them'), where impersonal si occurs with a verb, leggono, that seems to agree with the third plural person object clitic $l i$. In contrast, the verb does not agree with the object in SI. An explanation may lie in the contact between dialect and Italian: in Venetian, as well as in other Northern dialects, the order $l i$ si corresponds to a passive construction, i.e. formed with a $l i$-type subject clitic and a si-type passive clitic (e.g. Venetian $i$ se leze 'they are read'). Thus, in Italian li may be presumably reanalyzed as a subject clitic, which triggers the agreement (Cardinaletti 2009: 37-41). According to our framework, it seems furthermore likely that $l i$ is reanalyzed as a subject clitic only by dialect-speaking groups (presumably old and less educated persons, native speakers of dialect), while for other speakers $l i$ functions as an object clitic (and in this case the explanation of the construction may lie elsewhere, cf. e.g. Cardinaletti 2009: 41-42). Again, we would be dealing with "covert variants".

Finally, we must consider whether a given linguistic feature is obligatory or optional in a certain social or situational variety of RI. Broadly speaking, a feature or a set of features which is obligatory in a dialect, but not in SI, may tend to occur obligatorily in "folk" RI, where interrelated fossilized interferences may give rise to relatively lasting sub-systems substantially insensitive to style variation (cf. Sections 3.2 and 4). However, they do not obligatorily occur in situational varieties of RI. A case in point is object clitic doubling, which is diagnostic for the development of a verbal object marking in Italian. In certain contexts it obligatorily occurs in some Italo-Romance dialects and tends to occur equally obligatorily in "folk" RI (e.g. when clitic doubles a first or second singular person indirect object, as in ti dico a te 'I say to you', literally 'to you I say to you'), while it is widely optional and depends on pragmatic factors in situational varieties of RI. In particular, its frequency increases in colloquial and casual speech. This reflects an ongoing tendency in Romance. As for verbal object marking, the low-prestige varieties of Romance languages are generally at a more advanced developmental stage when compared to their high-prestige counterparts (cf. Cerruti 2008). 


\subsection{Regional markedness in contemporary Italian}

As I said earlier (Section 3.3), the ongoing process of convergence among the regional varieties of Italian tends to reduce the regional markedness of certain features. Similarly, due to both internal migrations and increasing exchanges and mobility, regional varieties of Italian are including linguistic features that come from other regional varieties, especially among the younger generation. The regional markedness of spoken Italian is thus noticeably decreasing nowadays. The present younger generation in particular speaks a sort of "composite" RI, consisting of linguistic features coming from different regional varieties of Italian, at least in terms of phonetics and phonology.

A research carried out in Rome in the early Nineties (Conti and Courtens 1992) has already provided signs of this tendency. Teenagers of the lower middle class, whose parents moved to Rome from various regions of Italy either before or soon after their birth, showed remarkable speech convergence towards the pronunciation patterns of their Roman schoolmates, thus producing some of the most characteristic traits of Roman Italian; e.g. degemination of intervocalic geminate alveolar trills (as in ['bi:ra] vs. SI ['bir:a] 'beer'), gemination of intervocalic voiced bilabial plosives (['ab:ile] vs. SI ['a:bile] 'able') and intervocalic voiced postalveolar affricates (['ad:3ile] vs. SI ['a:dzile] 'agile'), deaffrication of intervocalic voiceless postalveolar affricates (['vo:fe] vs. SI ['vo:tfe] 'voice'), etc. Nonetheless, the regional variety spoken by their Roman schoolmates did not show a great amount of regionally marked features.

As is well known, speech convergence generally undertakes social functions. The following example provides evidence of this. The so-called raddoppiamento fonosintattico ('phonosyntactic doubling'; ' e.g. ['va:do a'r:o:ma], vado a Roma 'I go to Rome') is a phonological feature of SI that occurs in Central and Southern regional varieties of Italian but not in the Northern varieties. Yet, it is attested in Turin Italian. Presumably as a result of the twentieth century massive internal migration from Southern Italy, it enjoys diffusion among certain adolescent groups (that present themselves as "communities of practice", cf. Boario [2008: 181-187]), which comprise both native speakers of Italian, whose parents come as much from Southern Italy as from Turin, and non-native speakers, whose parents have recently immigrated to Italy. It functions as a social marker of group membership and identity, closely associated with the social practices of the group; besides, as for the non-native speakers, it contributes to the attainment of a native-like identity (Boario 2008).

Finally, in peculiar circumstances, internal migrations may lead to the creation of a similar "composite" RI, leaving aside generation-specific uses of language. Let us consider the sociolinguistic situation of Latina, a town south of Rome. It was built in the 1920s and 1930s on a land that was once a swamp 


\section{M. Cerruti}

and founded in 1932 following land reclamation. Latina was populated at first by the compulsory settlement of farm hands coming from various regions of Italy, mainly from Veneto. These special circumstances have led to the formation of a local variety of Italian that is still now characterized by the coexistence of Roman and Northern regional features, ${ }^{8}$ the latter coming from Veneto RI. Examples of this merging process can be seen in the co-occurrence of affrication of pre-nasal voiceless alveolar fricative, a Roman feature, and raising of open-mid front unrounded vowel, a Northern RI feature, in [intsala'tje:ra] (vs. SI [insala'tje:ra] 'salad bowl'; Stefinlongo [2003: 100-101]).

\section{Conclusion}

In sum, research on RI offers a great deal of insight into a wide range of issues. Among others, I have dealt with the peculiarities of the process of language shift from dialects toward Italian, the question of the native speaker of Italian, the ongoing restandardization of the national language, the existence of "deeplevel" structural differences between SI and social varieties of RI, the sociogeographical diffusion of developmental tendencies of Italian, the relationship between diatopia, diastratia, and diaphasia, and the decreasing regional markedness of contemporary Italian. The regional varieties of Italian clearly demonstrate to be an outstanding observatory for synchronic and diachronic variation in Italian.

Università degli Studi di Torino

Correspondence address: massimosimone.cerruti@unito.it

\section{Notes}

1. Any estimate should however take into account that each dialect comprises several differences (that is, each village has its own variety, which can have further differences from hamlet to hamlet); on the basis of structural criteria, Italian scholars have identified more than a hundred varieties of dialects in Northern Italy alone (cf. Benincà 2001).

2. Albeit the concept of Umgangssprache is not perfectly suitable to the linguistic repertoire of Italy (Berruto 1987: 140-142).

3. Note that both "folk" Northern RI and SI have a T-V distinction; moreover, in both varieties second-person pronouns are used as the T-forms of address.

4. As well as others, which are related for example to the influence of English and the demand to be consistent with Standard Average European.

5. It follows that some regional features are socially marked but not sensitive to stylistic variation (e.g. if-clauses with conditional mood doubling: folk RI se potrei partire lo farei vs. SI se potessi partire lo farei 'if I could leave I would'). 
6. The variable (indossare) can indeed be realized either with the regional variants mettere addosso and mettere su or the pan-Italian variants mettere and indossare, the former being less formal and the latter more formal; none of these is substantially sensitive to social variation.

7. A process that causes gemination of the initial consonant of a word in specific morphosyntactic environments (e.g. after certain proclitics and oxytonic words).

8. To a lesser extent, in addition to Southern regional features (Stefinlongo 2003).

\section{References}

Alfonzetti, Giovanna. 1997. "Ora la luna si nascose, ma prima era bellissima". Passato prossimo e passato remoto nell'italiano di Sicilia. In Mari D'Agostino (ed.), Aspetti della variabilità, 11-48. Palermo: Centro di studi filologici e linguistici siciliani.

Amenta, Luisa. 1999. Tra lingua e dialetto: le perifrasi aspettuali nell'italiano regionale di Sicilia. Rivista Italiana di Dialettologia 23. 87-111.

Amenta, Luisa. 2008. Esistono verbi sintagmatici nel dialetto e nell'italiano regionale di Sicilia? In Monica Cini (ed.), I verbi sintagmatici in italiano e nelle varietà dialettali. Stato dell'arte e prospettive di ricerca, 159-174. Frankfurt am Main: Lang.

Ammon, Ulrich. 2004. Standard variety. In Ulrich Ammon, Norbert Dittmar, Klaus J. Mattheier \& Peter Trudgill (eds.), Sociolinguistics. An International Handbook of the Science of Language and Society, 2nd edn., vol. 1, 273-283. Berlin \& New York: Mouton de Gruyter.

Antonini, Francesca \& Bruno Moretti. 2000. Le immagini dell'italiano regionale. La variazione linguistica nelle valutazioni dei giovani ticinesi. Locarno: Dadò.

Benincà, Paola. 1994. Che cosa ci può dire l'italiano regionale. In Tullio De Mauro (ed.), Come parlano gli italiani, 157-165. Scandicci: La Nuova Italia.

Benincà, Paola. 2001. "Lingua" e "dialetto" alla luce della teoria linguistica. In Gianna Marcato (ed.), I confini del dialetto, 13-24. Padova: Unipress.

Benincà, Paola \& Federico Damonte. 2009. Varianti sintattiche inter- e intra-individuali nelle grammatiche dialettali. In Luisa Amenta \& Giuseppe Paternostro (eds.), I parlanti e le loro storie, 185-194. Palermo: Centro di studi filologici e linguistici siciliani.

Benincà, Paola \& Cecilia Poletto. 2006. Phrasal verbs in Venetian and Regional Italian. In Frans Hinskens (eds.), Language variation: European perspectives, 9-22. Amsterdam-Philadelphia: Benjamins.

Berretta, Monica. 1988. Italienisch: Varietätenlinguistik des Italienischen/Linguistica delle varietà. In Günter Holtus, Michael Metzeltin \& Christian Schmitt (eds.), Lexicon der Romanistischen Linguistik, vol. 4, 762-774. Tübingen: Niemeyer.

Berruto, Gaetano. 1987. Sociolinguistica dell'italiano contemporaneo. Roma: La Nuova Italia.

Berruto, Gaetano. 1989. Main topics and findings in Italian sociolinguistics. International Journal of the Sociology of Language 76 [Special issue: Italian sociolinguistics: Trends and issues]. $5-30$.

Berruto, Gaetano. 2003. Sul parlante nativo (di italiano). In Hans I. Radatz \& Rainer Schlösser (eds.), Donum grammaticorum. Festschrift für Harro Stammerjohann, 1-14. Tübingen: Niemeyer.

Berruto, Gaetano. 2005. Dialect/standard convergence, mixing, and models of language contact: the case of Italy. In Peter Auer, Frans Hinskens \& Paul Kerswill (eds.), Dialect change. Convergence and divergence in European languages, 81-97. Cambridge: Cambridge University Press.

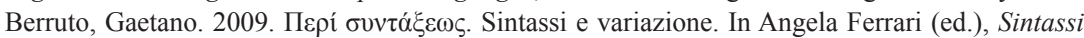
storica e sincronica dell'italiano. Subordinazione, coordinazione, giustapposizione, vol. 1, 2158. Firenze: Cesati. 


\section{M. Cerruti}

Bertinetto, Pier Marco. 2000. The progressive in Romance, as compared with English. In Östen Dahl (ed.), Tense and aspect in the languages of Europe, 559-604. Berlin \& New York: Mouton de Gruyter.

Biber, Douglas \& Susan Conrad. 2009. Register, genre and style. Cambridge: Cambridge University Press.

Binazzi, Neri. 1997. Le parole dei giovani fiorentini: variazione linguistica e variazione sociale. Roma: Bulzoni.

Binazzi, Neri. 2007. L'appartenenza rivelata. Lessico e tradizioni del discorso nel parlato fiorentino. Quaderni del Dipartimento di Linguistica dell'Università di Firenze 17. 137-168.

Boario, Anna. 2008. Community of practice e diffusione di un fenomeno alloctono a Torino trasmesso a parlanti immigrati non nativi. In Gaetano Berruto, Joseph Brincat, Sandro Caruana \& Cecilia Andorno (eds.), Lingua, cultura e cittadinanza in contesti migratori. Europa e area mediterranea, 165-189. Perugia: Guerra.

Bruni, Francesco (ed.). 1992. L'italiano nelle regioni. Lingua nazionale e identità regionali. Torino: UTET.

Bybee Joan, Revere Perkins \& William Pagliuca. 1994. The evolution of grammar: tense, aspect and modality in the language of the world. Chicago: University of Chicago Press.

Canepari, Luciano. 2005. MaPI. Manuale di pronuncia italiana. Bologna: Zanichelli.

Cardinaletti, Anna. 2009. Si impersonale e dimostrativi: due casi di influenza dei dialetti sull'italiano? In Anna Cardinaletti \& Nicola Munaro (eds.), Italiano, italiani regionali e dialetti, 2954. Milano: Franco Angeli.

Cardinaletti, Anna \& Nicola Munaro (eds.). 2009. Italiano, italiani regionali e dialetti. Milano: Franco Angeli.

Cerruti, Massimo. 2007. Sulla caratterizzazione aspettuale e la variabilità sociale d'uso di alcune perifrasi verbali diatopicamente marcate. Archivio Glottologico Italiano 92(2). 203-247.

Cerruti, Massimo. 2008. Condizioni e indizi di coniugazione oggettiva: i dialetti italiani settentrionali tra le lingue romanze. Rivista italiana di dialettologia 32. 13-38.

Cerruti, Massimo. 2009. Strutture dell'italiano regionale. Morfosintassi di una varietà diatopica in prospettiva sociolinguistica. Frankfurt am Main: Lang.

Cerruti, Massimo. Forthcoming a. Un fenomeno al confine tra morfosintassi e prosodia in una situazione di contatto verticale: le congiunzioni subordinanti ben che, fin che, per che. In Rita Franceschini, Raffaella Bombi, Mari D'Agostino \& Silvia Dal Negro (eds.), Lingue e culture in contatto. Perugia: Guerra.

Cerruti, Massimo. Forthcoming b. Premesse per uno studio della variazione di registro in italiano. Rivista italiana di dialettologia 33.

Cini, Monica (eds.). 2008. I verbi sintagmatici in italiano e nelle varietà dialettali. Stato dell'arte e prospettive di ricerca. Frankfurt am Main: Lang.

Cini, Monica \& Riccardo Regis (eds.). 2002. Che cosa ne pensa oggi Chiaffredo Roux? Percorsi della dialettologia percezionale all'alba del nuovo millennio. Alessandria: Dell'Orso.

Conti, Maria \& Gaelle Courtens. 1992. Standardizzazione e integrazione fonologica nella seconda generazione di immigrati a Roma: indagine su un gruppo di giovani. Rivista italiana di dialettologia 16. 255-281.

Cordin, Patrizia. 2009. Gli ausiliari essere e avere nell'italiano regionale trentino. In Anna Cardinaletti \& Nicola Munaro (eds.), Italiano, italiani regionali e dialetti, 69-98. Milano: Franco Angeli.

Cortelazzo, Michele A. \& Alberto M. Mioni (eds.). 1990. L'italiano regionale. Roma: Bulzoni.

Coseriu, Eugenio. 1980. "Historische Sprache" und "Dialekt". In Joachim Göschel, Ivic Pavle \& Kurt Kehr (eds.), Dialekt und Dialektologie, 106-122. Wiesbaden: Steiner.

Cucurullo, Nella, Simonetta Montemagni, Matilde Paoli, Eugenio Picchi \& Eva Sassolini. 2006. Un atlante dialettale in rete: $A L T-W E B$. In Elisa Corino, Carla Marello \& Cristina Onesti (eds.), 
Proceedings of the 12th Euralex International Congress (Torino, 6th-9th September, 2006). Alessandria: Dell'Orso.

D'Achille, Paolo. 1990. Sintassi del parlato e tradizione scritta della lingua italiana. Analisi di testi dalle Origini al secolo XVIII. Roma: Bonacci.

D’Achille, Paolo. 2002. L'italiano regionale. In Manlio Cortelazzo, Carla Marcato, Nicola De Blasi \& Gianrenzo P. Clivio (eds.), I dialetti italiani. Storia, struttura, uso, 26-42. Torino: UTET.

D'Achille, Paolo. 2003. Le "varietà romane" di italiano. In Paolo D'Achille \& Andrea Viviani (eds.), La lingua delle città. I dati di Roma, Latina, L'Aquila e Catania. Roma: Aracne.

D’Achille, Paolo \& Andrea Viviani (eds.). 2003. La lingua delle città. I dati di Roma, Latina, L'Aquila e Catania. Roma: Aracne.

Fusco, Fabiana. 2004. Ruolo e spazio comunicativo dell'italiano regionale nelle situazioni urbane. In Raffaella Bombi \& Fabiana Fusco (eds.), Città plurilingui. Lingue e culture a confronto in situazioni urbane, 275-289. Udine: Forum.

Fusco, Fabiana \& Carla Marcato (eds.) 2001. L'italiano e le regioni. [Special issue]. Plurilinguismo 8.

Gadet, Françoise. 2007. La variation sociale en français, 2nd edn. Paris: Ophrys.

Galli de' Paratesi, Nora. 1984. Lingua toscana in bocca ambrosiana. Tendenze verso l'italiano standard: un'inchiesta sociolinguistica. Bologna: Il Mulino.

Garzonio, Jacopo. 2008. Diacronia e sincronia della sintassi di punto in Fiorentino. Quaderni di lavoro ASIt 8. http://asis-cnr.unipd.it/papers.html (accessed 5 May 2010).

Giannelli, Luciano \& Leonardo M. Savoia. 1978. L'indebolimento consonantico in Toscana. Rivista Italiana di Dialettologia 2. 23-58.

Iacobini, Claudio \& Francesca Masini. 2009. I verbi sintagmatici dell'italiano fra innovazione e persistenza: il ruolo dei dialetti. In Anna Cardinaletti \& Nicola Munaro (eds.), Italiano, italiani regionali e dialetti, 115-135. Milano: Franco Angeli.

Labov, William. 2001. The anatomy of style-shifting. In Penelope Eckert \& John. R. Rickford (eds.), Style and sociolinguistic variation, 85-108. Cambridge: Cambridge University Press.

Loi Corvetto, Ines. 1982. L'italiano regionale di Sardegna. Bologna: Zanichelli.

Mattheier, Klaus J. 1996. Varietätenkonvergenz. Überlegungen zu einem Baustein einer Theorie der Sprachvariation. Sociolinguistica 10. 31-52.

Miglietta, Annarita \& Alberto A. Sobrero. 2003. Quanto sono regionali le varianti regionali, oggi? In Federico Albano Leoni, Francesco Cutugno, Massimo Pettorino \& Renata Savy (eds.), $I l$ parlato italiano. Napoli: D'Auria (CD-Rom).

Pandolfi, Elena M. 2006. Misurare la regionalità. Uno studio quantitativo su regionalismi e forestierismi nell'italiano palato nel Canton Ticino. Locarno: Dadò.

Pandolfi, Elena M. 2009. LIPSI-Lessico di frequenza dell'italiano parlato nella Svizzera italiana, Bellinzona: OLSI.

Parry, Mair. 2006. Il contatto linguistico: aspetti teorici e metodologici. In Alberto Sobrero \& Annarita Miglietta (eds.), Lingua e dialetto nell'Italia del duemila, 77-99. Galatina: Congedo.

Penello, Nicoletta \& Diego Pescarini. 2008. Osservazioni su mica in italiano e alcuni dialetti veneti. Quaderni di lavoro ASIt 8. http://asis-cnr.unipd.it/papers.html (accessed 5 May 2010).

Poletto, Cecilia. 2009. I costrutti verbo+preposizione: l'interferenza tra veneto e italiano regionale. In Anna Cardinaletti \& Nicola Munaro (eds.), Italiano, italiani regionali e dialetti, 155-172. Milano: Franco Angeli.

Posner, Rebecca. 1996. The Romance languages. Cambridge: Cambridge University Press.

Regis, Riccardo. 2006. Breve fenomenologia di una locuzione avverbiale: il solo più dell'italiano regionale piemontese. Studi di lessicografia italiana 23. 275-289.

Rizzi, Elena. 1989. Italiano regionale e variazione sociale: l'italiano a Bologna. Bologna: CLUEB. 


\section{M. Cerruti}

Rüegg, Robert. 1956. Zur Wortgeographie der Italienischen Umgangssprache. Köln: Kölner Romanistische Arbeiten.

Ruffino, Giovanni (eds.). 1995. Percorsi di Geografia linguistica. Palermo: Centro di studi filologici e linguistici siciliani.

Scholz, Arno. 2003. Comunicazione giovanile in rete: una mailing list italiana dedicata alla cultura hiphop. In Franz Rainer \& Achim Stein (eds.), I nuovi media come strumenti per la ricerca linguistica, 117-139. Frankfurt am Main: Lang.

Sobrero, Alberto A. 2006. Lecce: italiano e dialetto degli adulti, fra lavoro e media. In Alberto A. Sobrero \& Annarita Miglietta (eds.), Lingua e dialetto nell'Italia del duemila, 325-340. Galatina: Congedo.

Sobrero, Alberto A., Maria Teresa Romanello \& Immacolata Tempesta. 1991. Lavorando al Nadir: un'idea per un atlante linguistico. Galatina: Congedo.

Sogni, Alessandra. 2004. "Desso vado e ce lo dico”. Parlare con gli anziani in italiano popolare. Turin: University of Turin MA thesis.

Sornicola, Rosanna. 2006. Dialetto e processi di italianizzazione in un habitat del Sud d'Italia. In alberto A. Sobrero \& Annarita Miglietta (eds.), Lingua e dialetto nell'Italia del duemila, 195242. Galatina: Congedo.

Stefinlongo, Antonella. 2003. L'indagine nella città di Latina. Analisi sociolinguistica dei dati. In Paolo D'Achille \& Andrea Viviani (eds.), La lingua delle città. I dati di Roma, Latina, L'Aquila e Catania, 83-105. Roma: Aracne.

Stehl, Thomas. 1995. La dinamica diacronica fra dialetto e lingua: per un'analisi funzionale della convergenza linguistica. In Maria Teresa Romanello \& Immacolata Tempesta (eds.), Dialetti e lingue nazionali, 55-73. Roma: Bulzoni.

Telmon, Tullio. 1990. Guida allo studio degli italiani regionali. Alessandria: Dell'Orso.

Telmon, Tullio. 1993. Varietà regionali. In Alberto A. Sobrero (ed.), Introduzione all'italiano contemporaneo, vol. 2, 93-149. Roma-Bari: Laterza.

Telmon, Tullio. 2001. Italiani regionali tra interlingua, interculturalità e intervariazionalità. Plurilinguismo 8 [Special issue: L'italiano e le regioni]. 47-50.

Tempesta, Immacolata. 2002. Dal dialetto al repertorio, fra archivi e atlanti. Per un nuovo progetto regionale. In Gianna Marcato (ed.), La dialettologia oltre il 2001, 63-72. Padova: Unipress.

Thomason, Sarah \& Terrence Kaufman. 1988. Language contact, creolization, and genetic linguistics. Berkeley: University of California Press. 